\title{
Harga Diri, Sexting dan Jumlah Pasangan Seks yang Dimiliki oleh Pria Lajang Pelaku Perilaku Seks Berisiko
}

\author{
Wahyu Rahardjo', Maizar Saputra, Indria Hapsari \\ Fakultas Psikologi Universitas Gunadarma
}

\begin{abstract}
One of the risky sexual behaviors is the number of sexual partners individuals have. The higher number they have is the riskier for them to get infected by HIV/AIDS. The tendency to commit risky sexual behavior is higher in single person, and it said that mean committing it risky are more permissive than women. There have been researches studying the contribution of self-esteem to the number of sexual partners. Sexting is also assumed to have correlation with the number of sexual partners. The aim of this study was to measure the contribution of self-esteem and sexting to the number of sexual partners a single heterosexual man with risky sexual behaviors have. This study involved 83 participants. The result showed that the contribution of self-esteem to the number of sexual partners was $13.8 \%$ and sexting was $9.8 \%$ while the combination of self-esteem and sexting to the number of sexual partners was $13.2 \%$. The other findings indicated that the number of sexual partners varied in the participants based on educational background, while the self-esteem and sexting varied in them based on sexual orientation.
\end{abstract}

Keywords: self-esteem, sexting, number of sexual partners, risky sexual behavior

Abstrak. Salah satu bentuk perilaku seks berisiko adalah banyaknya jumlah pasangan seks yang dimiliki. Semakin banyak jumlah kepemilikan maka akan semakin berisiko individu terinfeksi HIV/AIDS. Kecenderungan untuk terlibat dalam perilaku seks berisiko menjadi lebih tinggi pada lajang, dan pria disebut sebagai figur yang terlibat perilaku seks berisiko lebih permisif dibandingkan wanita. Studi terdahulu menunjukkan peran harga diri terhadap banyaknya jumlah pasangan seks. Sexting juga diduga berkaitan dengan jumlah pasangan seks yang dimiliki. Tujuan penelitian ini adalah untuk mengukur peran harga diri dan sexting terhadap banyaknya jumlah kepemilikan pasangan seks pada pria heteroseksual lajang yang melakukan perilaku seks berisiko. Penelitian ini melibatkan sekitar 83 orang partisipan. Hasil penelitian memperlihatkan bahwa kontribusi harga diri terhadap jumlah pasangan seks sebesar $13.8 \%$ dan kontribusi sexting terhadap jumlah pasangan seks sebesar $9.8 \%$. Sementara itu kontribusi bersama-sama harga diri dan sexting terhadap jumlah pasangan seks sebesar $13.2 \%$. Temuan lain menunjukkan bahwa jumlah pasangan seks yang dimiliki berbeda pada kelompok partisipan berdasarkan latar belakang pendidikan. Adapun harga diri dan sexting berbeda pada kelompok partisipan berdasarkan orientasi seksual.

Kata kunci: harga diri, sexting, jumlah pasangan seks, perilaku seks berisiko

\footnotetext{
${ }^{1}$ Korespondensi mengenai artikel ini dapat dilakukan melalui: wahyu_rahardjo@yahoo.com
} 
Penyebaran HIV/AIDS ditengarai salah satunya karena perilaku seks berisiko. Salah satu bentuk perilaku seks berisiko adalah kepemilikan pasangan seks dalam jumlah banyak. Hal ini dapat terjadi karena jumlah pasangan seks yang banyak, linier dengan banyaknya jumlah hubungan seks. Di dalam banyak kasus, hubungan seks ini kerap terjadi tanpa disertai alat kontrasepsi (kondom).

Studi Fergus, Zimmerman, dan Caldwell (2007) yang menyatakan bahwa perilaku seks berisiko biasanya dimulai ketika individu memasuki usia remaja dan mencapai puncaknya ketika berada di usia dewasa awal. Mayoritas pelaku perilaku seks berisiko adalah individu yang berstatus lajang atau belum menikah (Riono, 2001). Studi Edelstein, Chopik, dan Kean (2011) menyatakan bahwa pria lajang atau yang belum menikah cenderung memiliki gairah seks yang tinggi karena mereka belum memiliki pasangan tetap untuk menyalurkan gairah seksnya.

Pria dikatakan sebagai figur yang tergolong rentan terhadap perilaku seks berisiko, bahkan lebih rentan dibandingkan wanita (Aidala dkk., 2006). Pria tergolong proaktif secara seksual, mengendalikan kontak seksual dan juga lebih permisif dalam hal seksualitas (Askun \& Ataca, 2007; Billy, Grady, \& Sill, 2009). Sementara itu, kepemilikan pasangan dalam jumlah banyak dipandang sebagai suatu pengakuan seksual (Paul, McManus, \& Heyes, 2000), terutama bagi pria. Memiliki pasangan seks dalam jumlah banyak membuat pria merasa hebat dan mendapatkan pengakuan dari teman sebaya.

Pada titik ini, terdapat peran harga diri dalam memengaruhi kepemilikan jumlah pasangan seks pada pria. Individu dengan harga diri yang rendah berusaha untuk mencari cara agar terlihat berharga bagi orang lain, salah satunya dengan memiliki banyak pasangan seks. Beberapa penelitian menemukan bahwa individu melakukan perilaku seks berisiko, salah satunya dengan memiliki pasangan seks dalam jumlah banyak karena memiliki harga diri yang negatif (Boden \& Horwood, 2006; Robinson, Holmbeck, \& Paikoff, 2007).

Variabel lain yang diduga berkaitan dengan kepemilikan pasangan seks dalam jumlah banyak adalah sexting. Sexting cenderung dilakukan oleh individu yang menganggap bahwa seks merupakan sesuatu yang menyenangkan dan memuaskan (Ferguson, 2011). Semakin tinggi kecenderungan individu melakukan sexting, semakin banyak pasangan seks yang dimiliki (Dake, Price, Maziarz, \& Ward, 2014).

Biasanya, pelaku sexting yang aktif atau bertipe two-way sexters juga berkaitan dengan hubungan seks yang dilakukan dengan pasangan tidak tetap. Sebelum bertemu dan melakukan hubungan seks, individu biasanya saling melakukan sexting terlebih dahulu (Benotsch, Snipes, Martin, \& Bull, 2013; Dir, Cyders, \& Coskunpinar, 2013). Penelitian Drouin, Vogel, Surbey, dan Stills (2013) juga menemukan bahwa sexting banyak dilakukan, baik dengan pasangan tetap maupun pasangan tidak tetap. Hal ini menjelaskan mengapa semakin sering sexting dilakukan guna menjajaki kemungkinan dilakukannya hubungan seks, biasanya semakin banyak pasangan seks tidak tetap yang dimiliki.

Pria, baik remaja maupun dewasa tergolong lebih mudah melakukan sexting dibandingkan wanita (Baumgartner dkk., 2014; West dkk., 2014). Dalam konteks hubungan romantis, pria lebih mudah melakukan sexting kepada siapa saja, sementara itu wanita membutuhkan 
komitmen dalam suatu hubungan sebelum melakukan sexting (Delevi \& Weisskirch, 2013).

\section{Harga Diri}

Harga diri merupakan suatu sikap positif tentang diri sendiri, bagaimana memberikan apresiasi terhadap diri sendiri (Guindon, 2010; Mruk, 2006). Harga diri juga dikatakan sebagai evaluasi diri yang sifatnya positif yang dirasakan oleh individu (Papalia, Olds, \& Feldman, 2004). Di sisi lain, Jategaonkar (2003) menjelaskan harga diri sebagai tingkatan atas kepuasan menyeluruh akan diri sendiri.

Franken (2002) menyebutkan bahwa harga diri dibagi menjadi dua, yaitu (1) harga diri positif atau kebanggaan diri yang secara sadar menerima kekurangan diri sendiri dan mengembangkan keunggulan diri serta kualitas-kualitas positif yang dimiliki oleh diri sendiri, dan (2) harga diri negatif atau perasaan malu yang datang dari penilaian diri sendiri sebagai individu dengan keterampilan dan kemampuan-kemampuan penting lain yang kurang dan tidak sebaik orang lain. Franken (2002) juga menyatakan bahwa harga diri yang dimiliki individu diperoleh dari tiga sumber, yaitu; (1) evaluasi diri, (2) kesuksesan yang diperoleh dari kegiatan-kegiatan utama, dan (3) nilainilai yang dianggap berharga secara sosial.

\section{Sexting}

Terdapat beberapa definisi mengenai sexting. Beberapa definisi mengenai sexting belum menegaskan bentuk nyata seperti apa texting tersebut. Salah satunya adalah Walker, Sanci, dan Temple-Smith (2013) yang menyebutkan sexting sebagai produksi dan distribusi gambar yang secara eksplisit mengandung seksualitas melalui teknologi komunikasi. Teknologi komunikasi belum disebutkan secara eksplisit seperti apa. Lebih lanjut, Gomez dan Ayala (2014) menyebutkan bahwa telepon genggam adalah media komunikasi terbaik dalam melakukan sexting.

Zhang (2010) menyatakan bahwa telepon genggam dapat digunakan untuk memotret dan menyebarkan gambar diri sendiri yang provokatif secara seksual. Pada kenyataannya, gambar bermuatan seks yang dibagi, tidak harus berupa tampilan diri sendiri, bahkan tidak hanya berupa gambar saja. Bauermeister, Yeagley, Meanley, dan Pingel (2014) menjelaskan bahwa sexting pada dasarnya berasal dari kata seks (sex) dan short message service atau pengiriman pesan pendek yang lazim disebut dengan SMS (texting).

Berdasrkan titik tolak tersebut, definisi texting yang paling komprehensif diberikan oleh beberapa orang, yaitu berbagi pesan, foto, gambar, dan juga video bermuatan seksual melalui telepon genggam (Drouin, Vogel, Surbey, \& Stills, 2013; Weisskirch \& Delevi, 2011). Berdasarkan definisi ini telepon genggam kemudian memiliki posisi sebagai atau computer mediated communication for transmitting sexual materials (CMC-S), Drouin, Vogel, Surbey, dan Stills, (2013). Di dalam definisi sexting tidak disebutkan kepada siapa individu melakukan sexting karena definisi sexting menitikberatkan pada konten dan media pengiriman, namun demikian banyak penelitian memang memfokuskan sexting yang dilakukan individu kepada pasangan romantisnya (Delevi \& Weisskirch, 2013).

Gordon-Messer, Bauermeister, Grodzinski, dan Zimmerman (2013) memaparkan bahwa terdapat beberapa tipe orang yang terlibat sexting. Pertama adalah receivers atau individu yang pernah menerima foto, gambar dan pesan seksual sugestif. Kedua adalah senders atau indi- 
vidu yang pernah mengirim foto, gambar, dan pesan seksual sugestif. Kemudian yang ketiga adalah two-way sexters atau individu yang pernah menerima dan mengirim foto, gambar, dan pesan seksual sugestif. Penelitian Strassberg, McKinnon, Sustaita, dan Rullo (2013) menyatakan bahwa individu yang terlibat sexting lebih banyak yang menerima dan mengirimkan kembali dibandingkan yang pasif atau yang hanya menerima saja.

\section{Jumlah Pasangan Seks}

Kepemilikan pasangan seks dalam jumlah banyak merupakan salah satu bentuk perilaku seks berisiko. Perilaku seks berisiko sendiri adalah keterlibatan individu dalam melakukan aktivitas seks yang memiliki risiko terpapar penyakit menular seksual seperti AIDS (Guin, 2005).

Studi Halkitis, Zade, Shrem, dan Marmor (2004) menyatakan bahwa rerata jumlah pasangan seks yang dimiliki oleh individu seumur hidupnya kurang lebih 20 orang. Sementara itu, studi lain menyebutkan rerata jumlah pasangan seks seumur hidup yang dapat dimiliki individu sejumlah 10 orang (Dodge, Jeffries IV, \& Sandfort, 2008).

Berdasarkan penjelasan yang telah dipaparkan sebelumnya maka hipotesis dalam penelitian ini adalah terdapat peran harga diri dan sexting terhadap jumlah pasangan seks yang dimiliki oleh pria pelaku perilaku seks berisiko berstatus lajang.

\section{Metode}

Variabel yang dilibatkan dalam penelitian ini adalah harga diri sebagai variabel prediktor pertama $(\mathrm{X} 1)$, sexting sebagai variabel prediktor kedua (X2), dan jumlah pasangan seks sebagai variabel kriterium $(\mathrm{Y})$.
Partisipan dalam penelitian ini berjumlah 83 orang pria yang berstatus lajang atau belum menikah. Rentang usia partisipan antara 17 hingga 31 tahun $(M E=$ 24.72; $S D=3.02)$. Mayoritas partisipan adalah karyawan $(n=46 ; 55.42 \%)$, diikuti oleh mahasiswa $(n=32 ; 38.55 \%)$ dan wiraswasta $(n=5 ; 6.02 \%)$. Mayoritas partisipan memiliki latar belakang pendidikan SMA $(n=47 ; 56.62 \%)$, diikuti S1 $(n=31 ; 37.34 \%)$, dan D3 $(n=5 ; 6.02 \%)$. Orientasi seks mayoritas partisipan adalah heteroseksual $(n=62 ; 74.69 \%)$, kemudian gay $(n=19 ; 22.89$ $\%)$, dan biseksual ( $n=2 ; 2.40 \%)$.

Harga diri. Harga diri merupakan suatu bentuk evaluasi diri atau suatu sikap positif mengenai diri sendiri (Mruk, 2006; Papalia Olds, \& Feldman, 2004). Skala harga diri di dalam penelitian ini menggunakan skala yang disusun oleh Rosenberg (1965). Skala ini memiliki aitem sejumlah 10 butir dengan skor reliabilitas sebesar 0.940 .

Sexting. Sexting adalah berbagi pesan, gambar, foto, dan video yang mensugesti secara seksual melalui perantara telepon genggam (Drouin, Vogel, Surbey, \& Stills, 2013; Weisskirch \& Delevi, 2011). Skala sexting di dalam penelitian ini disusun berdasarkan konsep milik Gordon-Messer, Bauermeister, Grodzinski, dan Zimmerman, (2013) yang terdiri dari dua aspek, yaitu menerima, dan berbagi. Skala ini terdiri dari 8 aitem dan memiliki skor reliabilitas sebesar 0.923 .

Jumlah pasangan seks. Keterangan mengenai jumlah pasangan seks diketahui melalui pertanyaan "Dalam kurun waktu 6 bulan terakhir, ada berapa orang pasangan seks yang Anda miliki?". Memiliki pasangan seks dalam jumlah yang banyak merupakan salah satu bentuk perilaku seks berisiko. Oleh karena itu, 
hanya partisipan yang menjawab yang memiliki lebih dari satu orang pasangan seks yang diikutsertakan pada penelitian ini. Sementara itu, pilihan jangka waktu 6 bulan terakhir dikarenakan pertimbangan memori partisipan dalam menghitung kembali dengan siapa mereka pernah berhubungan seks. Pilihan 3 bulan dianggap terlalu sempit, sedangkan pilihan 12 bulan dianggap terlalu lama dan beberapa partisipan yang aktif secara seksual seringkali lupa mengingat dengan berapa orang mereka pernah berhubungan seks. Penelitian Rahardjo (2013) adalah salah satu penelitian yang mempertimbangkan batasan waktu 6 bulan dalam mengetahui batasan jumlah orang dengan siapa partisipan berhubungan seks.

Terdapat beberapa teknik analisis data yang digunakan dalam penelitian ini sesuai dengan keperluan penelitian, yaitu regresi ganda, analisis varians satu jalur dan uji $t$.

\section{$\mathrm{H}$ a $\mathrm{s}$ i 1}

Berdasarkan Tabel 1 terlihat hasil normalitas untuk seluruh variabel. Sebaran skor untuk variabel harga diri, sexting, dan jumlah pasangan seks adalah tidak normal karena memiliki signifikansi $p>.05$.

Sementara itu untuk uji liniearitas terlihat bahwa antara harga diri dan jumlah pasangan seks memiliki hubungan yang liner. Hasil yang senada juga ditemui antara sexting dan jumlah pasangan seks. Paparan lebih lengkap terlihat pada Tabel 2.

Secara keseluruhan, harga diri partisipan tergolong sedang $(M E=35.88 ; S D=$ 5.99). Sementara itu sexting yang dilakukan partisipan tergolong tinggi $(M E=30.67$; $S D=4.51$ ). Adapun rerata jumlah pasangan seks yang dimiliki partisipan dalam kurun waktu enam bulan terakhir sebanyak 3.64 orang $(S D=1.59)$.

Hasil penelitian juga memperlihatkan korelasi negatif yang signifikan antara harga diri dan jumlah pasangan seks, serta sexting dan jumlah pasangan seks (Tabel 3).

Kontribusi harga diri terhadap jumlah pasangan seks sebesar $13.8 \%$. Adapun kontribusi sexting terhadap jumlah pasangan seks sebesar 9.8\%. Sementara itu, kontribusi harga diri dan sexting secara bersama-sama terhadap jumlah pasangan seks yang dimiliki sebesar 13.2\% (Tabel 4).

Tabel 1

Normalitas untuk Semua Variabel

\begin{tabular}{lccc}
\hline \multicolumn{1}{c}{ Variabel } & Kolmogorov-Smirnov & $\boldsymbol{p}$ & Keterangan \\
\hline Pasangan seks & 0.000 & $p>.05$ & Tidak normal \\
Harga diri & 0.000 & $p>.05$ & Tidak normal \\
Sexting & 0.000 & $p>.05$ & Tidak normal \\
\hline
\end{tabular}

Tabel 2

Linieritas untuk Semua Variabel

\begin{tabular}{lcccc}
\hline \multicolumn{1}{c}{ Variabel } & F & Sig. & $\boldsymbol{p}$ & Keterangan \\
\hline Harga diri dan jumlah pasangan seks & 18.802 & 0.000 & $p<.05$ & Linier \\
Sexting dan jumlah pasangan seks & 11.441 & 0.001 & $p<.05$ & Linier \\
\hline
\end{tabular}


RAHARDJO, DKK.

Tabel 3

Korelasi Harga Diri, Sexting, dan Jumlah Pasangan Seks

\begin{tabular}{lcc}
\hline & Harga Diri & Sexting \\
\hline Jumlah Pasangan Seks & $-0.386(p<.00)$ & $-0.330(p<.01)$ \\
\hline
\end{tabular}

Tabel 4

Kontribusi Harga Diri dan Sexting terhadap Jumlah Pasangan Seks

\begin{tabular}{lcc}
\hline & \multicolumn{2}{c}{ Jumlah Pasangan Seks } \\
\cline { 2 - 3 } & $\boldsymbol{R}^{2}$ & Adjusted $\boldsymbol{R}^{2}$ \\
\hline Harga Diri & $0.149(14.9 \%)$ & $0.138(13.8 \%)$ \\
Sexting & $0.109(10.9 \%)$ & $0.098(9.8 \%)$ \\
Harga Diri dan Sexting & $0.153(15.3 \%)$ & $0.132(13.2 \%)$ \\
\hline
\end{tabular}

Hasil penelitian ini juga memperlihatkan bahwa tidak ada perbedaan yang signifikan pada harga diri, sexting, dan jumlah pasangan seks yang dimiliki dalam kurun waktu enam bulan terakhir berdasarkan pekerjaan. Namun demikian terlihat bahwa partisipan mahasiswa memiliki skor harga diri tertinggi, diikuti oleh partisipan yang bekerja sebagai wiraswasta, dan karyawan. Hal yang hampir senada ditemukan pada sexting di mana mahasiswa memiliki kecenderungan paling sering melakukan sexting, diikuti partisipan kelompok karyawan dan wiraswasta. Adapun untuk jumlah pasangan seks yang dimiliki, terlihat bahwa kelompok karyawan memiliki pasangan seks dalam kurun waktu enam bulan terakhir paling banyak, diikuti oleh kelompok wiraswasta dan mahasiswa (Tabel 5).

Berdasarkan Tabel 6 terlihat bahwa tidak ada perbedaan harga diri dan sexting yang signifikan berdasarkan latar belakang pendidikan. Namun demikian terlihat bahwa kelompok partisipan dengan pendidikan D3 memiliki harga diri tertinggi diikuti oleh SMA dan S1. Adapun kelompok partisipan dengan pendidikan S1 memiliki rerata skor sexting tertinggi diikuti oleh kelompok partisipan dengan pendidikan D3 dan SMA. Sementara itu, terdapat perbedaan jumlah pasangan seks berdasarkan latar belakang pendidikan.

Tabel 5

Perbandingan Harga Diri, Sexting, dan Jumlah Pasangan Seks berdasarkan Pekerjaan

\begin{tabular}{lcccc}
\hline \multicolumn{1}{c}{ Variabel } & Kategori & ME (SD) & Skor & Signifikansi \\
\hline Harga Diri & Pekerjaan & & F=0.380 \\
& Mahasiswa & $36.04(5.89)$ & & \\
& Wiraswasta & $36.00(6.46)$ & & \\
& Karyawan & $33.60(3.91)$ & & \\
Sexting & Pekerjaan & & \\
& Mahasiswa & $31.31(5.03)$ & & \\
& Wiraswasta & $29.40(4.15)$ & & \\
& Karyawan & $30.37(4.18)$ & & \\
Jumlah & Pekerjaan & & & \\
Pasangan Seks & Mahasiswa & $3.50(1.54)$ & $F=0.209$ & \\
& Wiraswasta & $3.60(1.67)$ & & \\
& Karyawan & $3.74(1.65)$ & & \\
\end{tabular}


Tabel 6

Perbandingan Harga Diri, Sexting, dan Jumlah Pasangan Seks

Berdasarkan Latar Belakang Pendidikan

\begin{tabular}{lcccc}
\hline \multicolumn{1}{c}{ Variabel } & \multicolumn{1}{c}{ Kategori } & ME (SD) & Skor & Signifikansi \\
\hline Harga Diri & Pendidikan & & $F=1.118$ & $n s$. \\
& SMA & $36.23(5.90)$ & & \\
& D3 & $38.80(3.42)$ & & \\
Sexting & S1 & $34.87(6.36)$ & & $n s$. \\
& Pendidikan & & $F=1.669$ & \\
& SMA & $31.26(4.55)$ & & \\
Jumlah & D3 & $32.20(3.49)$ & & \\
Pasangan Seks & S1 & $34.87(6.36)$ & & \\
& Pendidikan & & & \\
& SMA & $3.32(1.47)$ & $F=3.158$ & \\
& D3 & $3.20(1.30)$ & & \\
& S1 & $4.19(1.70)$ & & \\
\hline
\end{tabular}

Kelompok partisipan dengan pendidikan S1 memiliki pasangan seks paling banyak dalam kurun waktu enam bulan terakhir diikuti oleh kelompok partisipan dengan pendidikan SMA dan D3.

Pada Tabel 7 terlihat bahwa ada perbedaan harga diri dan juga sexting yang signifikan berdasarkan orientasi seks. Untuk harga diri terlihat bahwa kelompok biseksual memiliki skor tertinggi diikuti oleh kelompok heteroseksual dan gay. Sementara itu untuk kelompok biseksual juga memiliki skor sexting tertinggi, diikuti oleh kelompok heteroseksual dan gay.

Di sisi lain, meskipun tidak ada perbedaan jumlah pasangan seks yang signifikan berdasarkan orientasi seks, namun terlihat bahwa kelompok gay memiliki rerata pasangan seks terbanyak dibandingkan kelompok biseksual maupun heteroseksual.

Pada Tabel 8 terlihat bahwa tidak ada perbedaan yang signifikan untuk semua variabel berdasarkan status berpacaran.

Tabel 7

Perbandingan Harga Diri, Sexting, dan Jumlah Pasangan Seks berdasarkan Orientasi Seks

\begin{tabular}{|c|c|c|c|c|}
\hline Variabel & Kategori & ME (SD) & Skor & Signifikansi \\
\hline \multirow[t]{4}{*}{ Harga Diri } & Orientasi seks & & $F=4.641$ & $p<.05$ \\
\hline & Heteroseksual & 36.89 (5.94) & & \\
\hline & Biseksual & $38.00(0.00)$ & & \\
\hline & Gay & 32.37 (5.19) & & \\
\hline \multirow[t]{4}{*}{ Sexting } & Orientasi seks & & $F=6.585$ & $p<.01$ \\
\hline & Heteroseksual & $31.52(4.31)$ & & \\
\hline & Biseksual & $33.50(0.70)$ & & \\
\hline & Gay & $27.63(4.05)$ & & \\
\hline Jumlah & Orientasi seks & & & \\
\hline \multirow[t]{3}{*}{ Pasangan Seks } & Heteroseksual & $3.44(1.47)$ & $F=2.057$ & $n s$. \\
\hline & Biseksual & $4.00(1.41)$ & & \\
\hline & Gay & $4.26(1.48)$ & & \\
\hline
\end{tabular}


RAHARDJO, DKK.

Tabel 8

Perbandingan Harga Diri, Sexting, dan Jumlah Pasangan Seks Berdasarkan Status Pacaran

\begin{tabular}{|c|c|c|c|c|}
\hline Variabel & Kategori & ME (SD) & Skor & Signifikansi \\
\hline \multirow[t]{3}{*}{ Harga Diri } & Status pacaran & & $t=-1.136$ & ns. \\
\hline & Pacaran & $34.86(5.27)$ & & \\
\hline & Sedang tidak pacaran & $36.43(6.32)$ & & \\
\hline \multirow[t]{3}{*}{ Sexting } & Status pacaran & & $t=0.123$ & ns. \\
\hline & Pacaran & $30.76(5.27)$ & & \\
\hline & Sedang tidak pacaran & $30.63(4.85)$ & & \\
\hline Jumlah & Status pacaran & & $t=-0.649$ & ns. \\
\hline Pasangan & Pacaran & $3.48(1.50)$ & & \\
\hline Seks & Sedang tidak pacaran & $3.72(1.65)$ & & \\
\hline
\end{tabular}

Namun beberapa hal yang menarik muncul, salah satunya adalah bahwa harga diri kelompok yang sedang tidak berpacaran justru lebih tinggi dibandingkan yang sedang berpacaran.

Pada Tabel 9 terlihat bahwa pasangan tetap merupakan jawaban yang paling sering disebut ketika partisipan diberi pertanyaan dengan siapa mereka pernah atau biasa melakukan sexting. Jawabanjawaban berikutnya adalah teman dengan jenis kelamin yang sama, teman berbeda jenis kelamin, baru yang terakhir adalah kekasih. Sementara itu, ketika ditanya mengenai motivasi melakukan sexting, maka jawaban yang paling sering muncul adalah sekedar berbagi, kemudian disusul oleh jawaban menggoda pasangan atau teman, lalu sebagai usaha awal agar dapat melakukan hubungan seks, dan yang terakhir adalah diminta pasangan atau teman.

\section{Diskusi}

Hasil penelitian ini menunjukkan bahwa rerata pasangan seks yang dimiliki dalam kurun waktu 6 bulan terakhir sejumlah sekitar 4.19 orang $(S D=1.70)$. Hal ini tidak jauh dari temuan beberapa penelitian sebelumnya yang menunjukkan angka 3.44 dan 4.55 orang (Rahardjo, 2013; 2014).

Tabel 9

Data Deskriptif mengenai Dengan Siapa Partisipan Melakukan Sexting dan Motivasi Melakukan Sexting

\begin{tabular}{|c|c|c|c|c|c|}
\hline \multicolumn{3}{|c|}{ Dengan Siapa Partisipan Melakukan Sexting } & \multicolumn{3}{|c|}{ Motivasi Melakukan Sexting } \\
\hline Kategori & Jumlah & Persentase & Kategori & Jumlah & Persentase \\
\hline Kekasih & 17 & 12.40 & $\begin{array}{l}\text { Menggoda pasangan / } \\
\text { teman }\end{array}$ & 34 & $30.90 \%$ \\
\hline Pasangan tidak tetap & 52 & $37.95 \%$ & $\begin{array}{l}\text { Usaha awal agar dapat } \\
\text { melakukan hubungan } \\
\text { seks }\end{array}$ & 14 & $12.72 \%$ \\
\hline $\begin{array}{l}\text { Teman berbeda jenis } \\
\text { kelamin }\end{array}$ & 23 & $16.78 \%$ & $\begin{array}{l}\text { Diminta pasangan / } \\
\text { teman }\end{array}$ & 12 & $10.90 \%$ \\
\hline $\begin{array}{l}\text { Teman dengan jenis } \\
\text { kelamin yang sama }\end{array}$ & 45 & $32.84 \%$ & Sekedar berbagi & 50 & $45.45 \%$ \\
\hline
\end{tabular}


Hasil penelitian ini juga menunjukkan bahwa harga diri memiliki peran terhadap kepemilikan pasangan seks dalam jumlah banyak sebesar $13.8 \%$ dengan korelasi negatif yang signifikan. Artinya, semakin rendah harga diri, maka akan semakin banyak jumlah pasangan seks yang dimiliki dalam kurun waktu enam bulan terakhir.

Temuan ini menegaskan bahwa jumlah pasangan seks yang banyak diasumsikan menjadi salah satu capaian pengakuan seksual bagi pria. Studi Zhang dkk. (2004) menjelaskan adanya persepsi bahwa sudah sewajarnya pria memiliki pasangan seks yang banyak. Kepemilikan pasangan seks dalam jumlah banyak terkadang menjadi salah satu hal yang dihargai di kalangan pria. Hal ini tentu menjadi sesuatu yang sifatnya normatif. Erickson (1999) bahkan menyatakan bahwa jumlah pasangan seks dan hubungan seks yang terkait dengannya menjadi sumber harga diri positif dan kompetensi sosial bagi pria. Senada dengan pendapat ini adalah hasil studi milik Gullete dan Lyons (2006) yang menemukan bahwa individu dengan harga diri yang negatif dan rendah cenderung memiliki pasangan seks lebih banyak dibandingkan individu dengan harga diri yang tinggi dan positif. Rahardjo (2014) dalam penelitiannya yang melibatkan mahasiswa juga menemukan bahwa semakin rendah harga diri akan semakin banyak jumlah pasangan seks yang dimiliki dalam kurun waktu 6 bulan terakhir.

Temuan yang juga menarik adalah adanya fakta bahwa korelasi dalam peran sexting terhadap jumlah pasangan seks yang dimiliki bersifat negatif. Hal ini berarti, semakin jarang individu terlibat dalam sexting maka semakin banyak pasangan seks yang dimiliki. Hasil ini tentu terkait dengan motivasi yang melatarbelakangi individu melakukan sexting.

Hasil penelitian ini mengungkap bahwa tidak ada perbedaan harga diri, sexting, dan jumlah pasangan seks berdasarkan pekerjaan partisipan. Meskipun demikian terdapat beberapa hasil yang cukup menarik. Misalnya saja, skor harga diri kelompok karyawan cenderung lebih rendah dibandingkan kelompok mahasiswa dan wiraswasta. Hal ini bisa saja terjadi mengingat karyawan biasanya bekerja dalam suatu struktur organisasi yang permanen dengan banyak aturan, dibandingkan wiraswastawan yang lebih bebas dalam bekerja atau mahasiswa yang memang belum terbebani dengan banyak hal berkaitan dengan pekerjaan. Banyak hal dapat menyebabkan karyawan memiliki harga diri yang rendah, misalnya stres kerja yang dirasakan (Lee, Jo, \& Choi, 2013).

Rendahnya harga diri kelompok karyawan ini terkait dengan temuan lainnya bahwa kelompok karyawan di sisi lain adalah kelompok partisipan yang memiliki rerata pasangan seks palin banyak dalam kurun waktu 6 bulan terakhir dibandingkan kelompok wiraswastawan dan mahasiswa. Temuan ini memperjelas mengapa harga diri berpengaruh secara negatif terhadap kepemilikan pasangan seks dalam jumlah banyak seperti yang telah disebutkan sebelumnya.

Mahasiswa menjadi kelompok yang memiliki rerata skor sexting paling tinggi. Hal ini dikarenakan mahasiswa memiliki waktu luang paling banyak dibandingkan kelompok partisipan lainnya. Mahasiswa adalah kelompok yang memiliki rentang usia yang berbeda, yaitu remaja akhir dan dewasa awal. Gomez dan Ayala (2012) menyatakan bahwa mayoritas pelaku sexting adalah remaja yang diikuti oleh dewasa awal. Remaja sendiri adalah masa- 
masa di mana individu memiliki banyak rasa ingin tahu dan melakukan eksplorasi seksualitas. Hal ini menjelaskan mengapa remaja yang kemudian memiliki sikap yang relatif positif terhadap seksualitas menjadi lebih rentan melakukan sexting (Samimi \& Alderson, 2014; van Ouytsel, van Gool, Ponnet, \& Walrave, 2014).

Beberapa studi juga menemukan bahwa remaja yang tidak merasa risih dalam menerima sexting cenderung lebih mudah meneruskannya kepada orang lain (Lee, Moak, \& Walker, 2013; Peskin dkk., 2013). Sementara itu, studi lain menyatakan bahwa dewasa awal juga disebut sebagai kelompok yang juga kerap terlibat sexting, bahkan lebih sering dibandingkan remaja (Klettke, Hallford, \& Mellor, 2014).

Temuan penelitian ini memperlihatkan perbedaan jumlah pasangan seks berdasarkan tingkat pendidikan. Kelompok partisipan dengan pendidikan S1 justru memiliki rerata jumlah pasangan seks paling tinggi dibandingkan dua kelompok lainnya. Banyaknya jumlah pasangan seks sebagai bagian dari perilaku seks berisiko seharusnya dipengaruhi oleh pemahaman dan pengetahuan akan AIDS. Pemahaman dan pengetahuan akan AIDS merupakan aspek kognisi di mana aspek ini kerap tidak berkaitan dengan latar belakang pendidikan (Amirullah, 2014). Pemahaman yang akurat memang lebih ditunjukkan oleh individu dengan latar belakang pendidikan yang tinggi (Rahardjo \& Rini, 2009).

Kelompok partisipan gay memiliki skor harga diri paling rendah di antara dua kelompok lainnya. Meskipun dewasa ini masyarakat kian toleran terhadap keberadaan gay, namun tetap saja gay memiliki problematika sendiri berkaitan dengan eksistensi mereka dan memengaruhi harga diri mereka (Gray \& Desmarais, 2014). Rasa malu, kebutuhan dan konse- kuensi coming out termasuk dalam beberapa hal yang dianggap dapat menimbulkan harga diri negatif pada gay (Bybee, Sullivan, Zielonka, \& Moes, 2009; Greene \& Britton, 2013; Schubotz \& McNamee, 2009).

Partisipan yang memiliki orientasi seks sebagai gay memiliki skor sexting paling rendah di antara kelompok yang lain. Hal ini mungkin disebabkan karena figur tempat berbagi konten sexting terbatas karena sesama pria, berbeda dengan pria heteroseksual yang memiliki figur berbagi sexting lebih banyak. Sementara itu, kelompok biseksual memiliki jumlah pasangan seks lebih banyak dibandingkan kelompok gay dan heteroseksual. Studi Everett dkk. (2014) juga menemukan hal senada bahwa kelompok biseksual yang cenderung lebih permisif dalam hal seksualitas, memang memiliki jumlah pasangan seks lebih banyak, bahkan dibandingkan dengan kelompok biseksual.

Temuan penelitian ini juga menunjukkan bahwa pasangan tidak tetap merupakan figur dengan siapa partisipan paling sering melakukan sexting. Figur yang berada dalam posisi berikutnya adalah teman sesama jenis kelamin. Hal ini menjadi lebih menarik ketika disandingkan dengan temuan lain yang mengungkap bahwa motivasi melakukan sexting yang paling sering disebut oleh partisipan adalah sekedar berbagi, dan diikuti oleh maksud menggoda pasangan atau teman. Hal ini menunjukkan bahwa mayoritas partisipan melakukan sexting sebagai perilaku ringan yang bertujan untuk sekedar berbagi dan menggoda pasangan atau teman saja. Itu dilakukan kepada pasangan tidak tetap dan teman dari jenis kelamin yang sama.

Studi Drouin, Vogel, Surbey, dan Stills (2013) menyatakan bahwa sexting belum menjadi cara yang efektif dalam mencari pasangan seks sebab hanya berada di 
urutan keempat yang paling banyak disebut sebagai motivasi melakukan sexting setelah untuk menggoda pasangan, permintaan pasangan, dan rasa malu mengekspresikan seksualitas jika harus bertemu langsung. Temuan Rahardjo, Hapsari, dan Saputra (2014) menemukan hal yang nyaris senada dengan temuan penelitian ini bahwa menggoda pasangan atau teman merupakan jawaban yang paling sering disebut ketika partisipan ditanya alasan melakukan sexting, baru disusul oleh niat untuk berbagi, serta usaha awal melakukan hubungan seks.

Motivasi melakukan sexting disebut sebagai hal yang krusial. Hal ini terjadi sebab keberadaan saudara kandung, orang tua, dan guru kurang memiliki peran dalam perilaku sexting, kalah dari norma subjektif yang diyakini muncul melalui teman sebaya (van Ouytsel, Walrave, Ponnet, \& Heirman, 2014).

Kesehatan mental disebut sebagai hal yang melatarbelakangi motivasi melakukan sexting (Gordon-Messer, Bauermeister, Grodzinski, \& Zimmerman, 2013; Temple, Le, van den Berg, Ling, Paul, \& Temple, 2014). Beberapa permasalahan sederhana yang dapat menjadi contoh adalah kebosanan, kesepian, dan kebutuhan akan intimasi (Drouin \& Tobin, 2014). Namun demikian hal itu bisa jadi lebih krusial jika memang sexting dilakukan dengan niat utama sebagai ekspresi seksual, mencari pasangan seks selain pasangan tetap, atau bahkan sebagai sebagai usaha awal melakukan hubungan seks dengan orang yang menjadi partner sexting seperti yang ditemukan di beberapa penelitian sebelumnya (Drouin, Vogel, Surbey, \& Stills, 2013; Klettke, Hallford, \& Mellor, 2014). Kendati demikian, sexting dianggap cukup sulit dihentikan mengingat banyak individu tidak mengetahui keterkaitan aspek hukum dalam sexting (Zhang, 2010), dan sebaliknya terlibat dalam sexting kerap dianggap sebagai pengalaman yang menyenangkan (Stocker, 2013).

\section{Kesimpulan}

Berkaitan dengan hasil penelitian ini, terdapat beberapa kesimpulan yaitu; Pertama, harga diri dan sexting memiliki peran dalam mendorong individu memiliki pasangan seks dalam jumlah banyak. Kedua, harga diri dan sexting secara berbeda ditunjukkan oleh partisipan dengan orientasi seks yang berbeda pula. Ketiga, pada dasarnya sexting yang dilakukan oleh partisipan dalam penelitian ini dikarenakan hanya ingin berbagi konten seksualitas, mayoritas dilakukan kepada pasangan tidak tetap atau kepada teman dari jenis kelamin yang sama.

\section{Saran}

Saran-saran yang dapat dikedepankan berdasarkan hasil penelitian ini; Pertama, konten sexting belum terfokus. Sebaiknya lebih dijelaskan secara lebih lanjut apakah objek sexting adalah diri sendiri atau orang lain. Kedua, partisipan wanita juga dapat dilibatkan untuk membuat hasil penelitian menjadi lebih variatif. Hal ini dikarenakan selain bukan pelaku perilaku seks berisiko yang seaktif pria, namun wanita juga dianggap memiliki motivasi melakukan sexting yang berbeda dibandingkan pria.

\section{Kepustakaan}

Aidala, A. A., Lee, G., Garbers, S., \& Chiasson, M.A. (2006). Sexual behaviors and sexual risk in a prospective cohort of HIV-positive men and women in New York City, 1994-2002: Implications for prevention. AIDS Education and Prevention, 18, 12-32. 
Amirullah, R. (2014). Hubungan pengetahuan akan AIDS dan perilaku seks pranikah pada remaja. (Skripsi tidak dipublikasikan). Jakarta: Fakultas Psikologi Universitas Gunadarma.

Askun, D., \& Ataca, B. (2007). Sexually related attitudes and behaviors of Turkish university students. Archieves of Sexual Behavior, 36(5), 741-752.

Bauermeister, J. A., Yeagley, E., Meanley, S., \& Pingel, E. S. (2014). Sexting among young men who have sex with men: Result from a national survey. Journal of Adolescent Health, 54, 606-611.

Baumgartner, S. E., Sumter, S. R., Peter, J., Valkenburg, P. M., \& Livingstone, S. (2014). Does coutry context matter? Investigating predictors of teen sexting across Europe. Computers in Human Behavior, 34, 157-164.

Benotsch, E. G., Snipes, D. J., Martin, A. M., \& Bull, S. S. (2013). Sexting, substance use, and sexual risk behaviors in young adults. Journal of Adolescent Health, 52, 307-313.

Billy, J. O. G., Grady, W. R., \& Sill, M. E. (2009). Sexual risk-taking among adult dating couples in the United States. Perspective on Sexual and Reproductive Health, 41, 74-83.

Boden, J. M., \& Horwood, L. J. (2006). Selfesteem, risky sexual behavior, and pregnancy in New Zealand birth cohort. Archive Sexual Behavior, 35(5), 549-560.

Bybee, J. A., Sullivan, E. L., Zielonka, E., \& Moes, E. (2009). Are gay men in worse mental health than heterosexual men? The role of age, shame and guilt, and coming out. Journal of Adult Development, $16,144-154$.

Dake, J. A., Price, J. H., Maziarz, L., \& Ward, B. (2012). Prevalence and correlates of sexting behavior in adolescents. American Journal of Sexuality Education, 7, 1-15.

Delevi, R., \& Weisskirch, R. S. (2013). Personality factors as predictors of sexting. Computers in Human Behavior, 29, 2589-2594.

Dir, A. L., Cyders, M. A., \& Coskunpinar, A. (2013). From the bar to the bed via mobile phone: A first test of the role of problematic alcohol use, sexting and impulsivity-related traits in sexual hookups. Computers in Human Behavior, 29, 1664-1670.

Dodge, B., Jeffries IV, W. L., \& Sandfort, T. G. M. (2008). Beyond the down low: Sexual risk, protection, and disclosure among at-risk Black men who have sex with both men and women (MSMW). Archives of Sexual Behavior, 37, 683-696.

Drouin, M., \& Tobin, E. (2014). Unwanted but consensual sexting among young adults: Relations with attachment and sexual motivations. Computers in Human Behavior, 31, 412-418.

Drouin, M., Vogel, K. N., Surbey, A., \& Stills, J. R. (2013). Let's talk about sexting, baby: Computer-mediated sexual behaviors among young adults. Computers in Human Behavior, 29, A25A30.

Edelstein, R. S., Chopik, W. J., \& Kean, E. L. (2011). Sociosexuality moderates the association between testosterone and relationship status in men and women. Hormones and Behavior, 60, 248-255.

Erickson, J. M. (1999). The relation of constructive and destructive deviance to sexual behavior in late adolescence. Unpublished dissertation. Missouri: University of Missouri-Columbia.

Everett, B. G., Schnarrs, P.W., Rosario, M., Garofalo, R., \& Mustanski, B. (2014). Sexual orientation disparities in sexually transmitted infection risk behaviors and risk determinants among sexually active adolescent males: Results from a schoolbased sample. American Journal of Public Health, 104, 1107-1112.

Fergus, S., Zimmerman, M. A., \& Caldwell, C. H. (2007). Growth tranjectories of sexual risk behavior in adolescence and young adulthood. American Journal of Public Health, 97, 1006-1101. 
Ferguson, C. J. (2011). Sexting behaviors among young Hispanic women: Insidence and association with other high-risk sexual behaviors. Psychiatry Quarterly, 82, 239-243.

Franken, R. E. (2002). Human motivation (fifth edition). Belmont: Wardsworth.

Gomez, L. C., \& Ayala, E. S. (2014). Psychological aspects, attitudes and behaviour related to the practice of sexting: A systematic review of the existent literature. Procedia Social and Behavioral Sciences, 132, 114-120.

Gordon-Messer, D., Bauermeister, J. A., Grodzinski, A., \& Zimmerman, M. (2013). Sexting among young adults. Journal of Adolescent Health, 52, 301-306.

Gray, A., \& Desmarais, S. (2014). Not all one and the same: Sexual identity, activism, and collective self-esteem. The Canadian Journal of Human Sexuality, 23, 116-122.

Greene, D. C., \& Britton, P. J. (2013). The influence of forgiveness on lesbian, gay, bisexual, transgender, and questioning individuals' shame and self-esteem. Journal of Counseling \& Development, 91, 195-205.

Guin, A. H. (2005). Sexual risk behavior in college students: Does the parent-college student relationship impact students' condom use? Unpublished dissertation. Raleigh: North Carolina State University.

Guindon, M. H. (2010). What is self-esteem. Dalam M.H. Guindon, (Ed.), Self-esteem across the lifespan: Issues and interventions. New York: Routledge.

Gulette, D. L., \& Lyons, M. A. (2006). Sensation seeking, self-esteem, and unprotected sex in college students. Journal of the Association of Nurses in AIDS Care, 17, 23-31.

Halkitis, P. N., Zade, D. D., Shrem, M., \& Marmor, M. (2004). Beliefs about HIV noninfection and risky sexual behavior among MSM. AIDS Education and Prevention, 16, 448-458.
Jategaonkar, N. (2003). Association of body image and self-esteem and condom selfefficacy with risky sexual behavior among Canadian grade 11 students. Unpublished thesis. Kingston: Queen's University.

Klettke, B., Hallford, H. J., \& Mellor, D. J. (2014). Sexting prevelance and correlates: A systematic literature review. Clinical Psychology Review, 34, 44-53.

Lee, C. H., Moak, S., \& Walker, J. T. (2013). Effects of self-control, social control, and social learning on sexting behavior among South Korean youths. Youth $\mathcal{E}$ Society, 20, 1-23.

Mruk, C. J. (2006). Self-esteem research, theory, and practice: Toward a positive psychology of self-esteem (3rd edition). New York: Springer Publising Company.

Papalia, D. E., Olds, S. W., \& Feldman, R. D. (2004). Human development (ninth edition). New York: McGraw-Hill.

Paul, E. L., B. McManus, \& A. Hayes. (2000). "Hookups": Characteristics and correlates of college students' spontaneous and anonymous sexual experiences. The Journal of Sex Research, 37, 76-88.

Peskin, M. F., Markham, C. M., Addy, R. O., Shegog, R., Thiel, M., \& Tortolero, S. R. (2013). Prevalence and patterns of sexting among ethnic minority urban high school students. Cyberpsychology, Behavior, and Social Networking, 16, 454459.

Rahardjo, W., \& Rini, Q. K. (2009). Pengetahuan akan AIDS pada Mahasiswa: Sampai sejauh apa? (Laporan penelitian tidak dipublikasikan). Depok: Fakultas Psikologi Universitas Gunadarma.

Rahardjo, W. (2013). Model perilaku seks berisiko pada pria. (Disertasi tidak dipublikasikan). Yogyakarta: Fakultas Psikologi Universitas Gadjah Mada.

Rahardjo, W. (2014). The roles of self-estem and motivation of having an affair towards the number of multiple sex 
partners and sexual intimacy among college students who engage in risky sexual behavior. Australian Journal of Basic and Applied Sciences, 8, 171-175.

Rahardjo, W., Hapsari, I., \& Saputra, M. (2014). Kecenderungan mencari sensasi seksual, sexting, dan perilaku seks berisiko pada pelaku sexting tipe twoway sexters. Makalah. Dipresentasikan pada Temu Ilmiah Nasional \& Kongres HIMPSI XII, Manado 11-14 September 2014.

Riono, P. (2001). Sexual network among men and STDs/HIV epidemic in Indonesia. Unpublished dissertation. Los Angeles: University of California.

Robinson, M. L., Holmbeck, G. N., \& Paikoff, R. (2007). Self-esteem enhancing reasons for having sex and the sexual behaviors of African American adolescents. Journal of Youth Adolescence, 36, 453-464.

Rosenberg, M. (1965). Socienty and the adolescent self-image. New Jersey: Princenton University Press.

Samimi, P., \& Alderson, K. G. (2014). Sexting among undergraduate students. Computers in Human Behavior, $31,230-241$.

Schubotz, D., \& McNamee, H. (2009). "I knew I wasn't like anybody else": Young men's account of coming out and being gay in Northern Ireland. Child Care in Practice, 15, 193-208.

Stocker, K. (2013). Young adult's experience of sexting in America. Unpublished dissertation. San Francisco: California School of Professional Psychology.

Strassberg, D. S., McKinnon, R. K., Sustaita, M. A., \& Rullo, J. (2013). Sexting by high school students: An exploratory and descriptive study. Archieves of Sexual Behavior, 42, 15-21.

Temple, J. R., Le, V. D., van den Berg, P., Ling, Y., Paul, J. A., \& Temple, B. W. (2014). Teen sexting and psychosocial health. Journal of Adolescence, 37, 33-36.

van Ouytsel, J., van Gool, E., Ponnet, K., \& Walrave, M. (2014). The association between adolescents' characteristics and engagement in sexting. Journal of Adolescence, 37, 1387-1391.

Van Ouytsel, J., Walrave, M., Ponnet, K., \& Heirman, W. (2014). The association between adolescent sexting, psychosocial difficulties, and risk behavior: Integrative review. The Journal of School Nursing, 1, 1-16.

Walker, S., Sanci, L., \& Temple-Smith, M. (2013). Sexting: Young women's and men's view on its nature and origin. Journal of Adolescent Health, 52, 679-701.

Weisskirch, R. S., \& Delevi, R. (2011). "Sexting" and adult romantic attachment. Computers in Human Behavior, 27, 1697-1701.

West, J. H., Lister, C. E., Hall, P. C., Crookston, B. T., Snow, P. R., Zvietcovich, M. E., \& West, R. P. (2014). Sexting among Peruvian adolescents. BMC Public Health, 14, 811-818.

Zhang, H., Stanton, B., Li, X., Mao, R., Sun, Z., Kaljee, L., Clemens, M., Ravendran, S., \& Qu, M. (2004). Perceptions and attitudes regarding sex and condom use among Chinese college students: A qualitative study. AIDS and Behavior, 8, 105-117.

Zhang, X. (2010). Charging children with child pornography: Using the legal system to handle the problem of "sexting". Computer Law \& Security Review, 26, 251-259. 